\title{
Bacterial biofilm formation in the urinary bladder of spinal cord injured patients
}

G Reid PhD, ${ }^{1,2}$ R Charbonneau-Smith RN,${ }^{3}$ D Lam MSc, ${ }^{1}$ Yun Suk Kang, student, ${ }^{1}$ M Lacerte $\mathrm{MD}^{3} \mathrm{KC}$ Hayes $\mathrm{PhD}^{3}$

${ }^{1}$ Department of Microbiology and Immunology, University of Western Ontario, London, Ontario, Canada; ${ }^{2}$ Division of Urology, Department of Surgery, University of Toronto, Ontario, Canada; ${ }^{3}$ Department of Physical Medicine and Rehabilitation, Parkwood Hospital and University of Western Ontario, London, Ontario, Canada.

Ten spinal cord injured patients aged 8 to 55 years (mean 32) were followed for up to 2 months after admisssion to a rehabilitation setting from an acute care hospital. Urinary fluid and bladder epithelial cells were collected weekly by intermittent catheterization and examined for bacterial colonization. Six patients had no history of urinary tract infection upon admission, likely due to the antimicrobial coverage given during acute care. All the patients subsequently became colonized with uropathogens at some time during the study period. Bacterial biofilms were found in $73 \%$ of the samples $(73 \%$ Gram negative organisms, $27 \%$ Gram positive), with mean pathogenic adhesion counts of 29 organisms per bladder cell. In $16 \%$ of cases, bladder biofilms were found when urine culture was negative. Bacterial biofilms were also evident during antimicrobial therapy in 10 of 12 samples tested and urine cultures showed breakthrough infections in $50 \%$ of cases. Two asymptomatic patients were colonized with Klebsiella pneumoniae and Pseudomonas aeruginosa and were dismissed without requiring therapy. Clearly, bacterial biofilms can exist on bladder epithelia, without being detected in urine samples and without giving rise to symptoms. The extent to which they occur and damage the host remains to be determined, as does the answer to the question, should these patients be treated?

Keywords: Spinal cord injury; urinary infection; bacterial biofilms; bladder.

\section{Introduction}

Urinary tract infections (UTI) still remain a major cause for concern, particularly amongst adult females, acute and chronic care patients ${ }^{1-3}$ and spinal cord injured (SCI) patients. ${ }^{4}$ Although the treatment of symptomatic UTI is reasonably well managed with administration of antimicrobial agents, ${ }^{5}$ the approach to asymptomatic infections is more controversial. Often, only symptomatic infection with more than 1000 to 100,000 organisms per $\mathrm{ml}$ urine is deemed significant and worthy of therapy. 5,6 The finding of similar numbers of uropathogens

Correspondence: Office of Research Services, SLB 328, University of Western Ontario, London, Ontario, N6A 5B8, Canada. in the bladder without symptoms is invariably left untreated to prevent emergence of drug resistant organisms or strains that somehow might induce symptoms.

The pathogenesis of UTI has been shown to involve the adhesion of uropathogens onto uroepithelial cells. ${ }^{7}$ One in vitro study showed that strains from symptomatic patients could adhere to bladder cells in larger numbers and that those from asymptomatic patients were poorly or non adherent. ${ }^{8}$ Once attached, the organisms aggregate and form biofilms that can serve as a focus for persistent infection and that can resist the action of antimicrobial agents. ${ }^{9,10}$

The hypotheses of the present study were: (a) that adherent bacterial biofilms formed in the bladders of spinal cord injured patients who required catheterization; (b) that 
these biofilms need not correspond to urinary culture findings; and (c) that they could resist the action of antimicrobial agents.

\section{Patients and methods}

Ten patients with SCI provided written consent to participate in the study, after approval of the protocol by the Parkwood Hospital, London, Ontario and University of Western Ontario Health Review Boards. These SCI patients were all managing their bladder by intermittent catheterization. The study was commenced within 6 months of the occurrence of their injuries. Information on the patients is provided in Table I.

Each Monday for up to 2 months, the patients provided a sterile urine specimen via an intermittent urinary catheter. The sample was split into 2 beakers; one was sent for routine microbiological culture quantitation, while the other was centrifuged and the sediment bladder cells were air dried, Gram stained and examined for adherent Gram positive and Gram negative bacteria. Fifty cells were counted per sample and mean adhesion counts were tabulated.

\section{Results}

The average study time for the 10 patients was 6.7 weeks, as 4 patients were discharged prior to the end of the 2 months. A total of 49 samples were taken, with occasional gaps during the time course due to difficulties with coordinating the patient specimens and delivery for testing. Within this time, all 10 patients developed bladder colonization, signified by urine culture (all were $>10^{5}$

Table I Information on the $10 \mathrm{SCl}$ patients prior to their entry into this study

\begin{tabular}{|c|c|c|c|c|c|c|}
\hline \multirow[t]{2}{*}{ Patient } & \multirow[t]{2}{*}{ Age/Sex } & \multirow[t]{2}{*}{ Injury } & \multirow{2}{*}{$\begin{array}{l}\text { UTI upon } \\
\text { admission }\end{array}$} & \multicolumn{2}{|c|}{ UTI in $\mathrm{PH}$} & \multirow[t]{2}{*}{ Treatment } \\
\hline & & & & Org & Symp & \\
\hline 1 & $22 / \mathrm{F}$ & $\begin{array}{l}\text { Complete } \\
\mathrm{C}_{7} \text { quad }\end{array}$ & Yes & $1,2,3$ & Sympt & $\begin{array}{l}\text { A, B, C, D, } \\
\text { E, F }\end{array}$ \\
\hline 2 & $19 / \mathrm{F}$ & $\begin{array}{l}\text { Complete } \\
\mathrm{T}_{4} \text { para }\end{array}$ & Yes & 2 & Sympt & $\mathrm{D}, \mathrm{F}$ \\
\hline 3 & $8 / \mathrm{F}$ & $\begin{array}{l}\text { Complete } \\
\mathrm{T}_{6} \text { para }\end{array}$ & Yes & 2 & Sympt & A \\
\hline 5 & $51 / \mathrm{M}$ & $\begin{array}{l}\text { Incomplete } \\
\mathrm{T}_{7} \text { para }\end{array}$ & No & $1,2,4,5$ & Asympt & $\mathrm{D}, \mathrm{F}$ \\
\hline 6 & $29 / \mathrm{M}$ & $\begin{array}{l}\text { Incomplete } \\
\mathrm{C}_{6} \text { quad }\end{array}$ & Yes & $\begin{array}{l}6 \\
3\end{array}$ & $\begin{array}{l}\text { Sympt } \\
\text { Sympt }\end{array}$ & $\mathrm{F}, \mathrm{G}$ \\
\hline 7 & $33 / \mathrm{M}$ & $\begin{array}{l}\text { Complete } \\
\mathrm{T}_{6-7} \text { para }\end{array}$ & No & 0 & & \\
\hline 8 & $37 / \mathrm{M}$ & $\begin{array}{l}\text { Incomplete } \\
\mathrm{C}_{4} \text { quad }\end{array}$ & No & 0 & & \\
\hline 9 & $29 / \mathrm{M}$ & $\begin{array}{l}\mathrm{C}_{6-7} \text { fracture } \\
\text { dislocation }\end{array}$ & No & 0 & & \\
\hline 10 & $55 / \mathrm{M}$ & $\begin{array}{l}\text { Incomplete } \\
\mathrm{C}_{5} \text { quad }\end{array}$ & No & 0 & & \\
\hline 11 & $34 / \mathrm{M}$ & $\begin{array}{l}\mathrm{C}_{5-6} \text { fracture } \\
\text { dislocation }\end{array}$ & No & 0 & & \\
\hline
\end{tabular}

$\mathrm{F}=$ female $; \quad \mathrm{M}=$ male $; \quad$ Quad = quadraplegic $\cdot$ Para = paraplegic $; \quad \mathrm{PH}=$ Parkwood Hospital; UTI = urinary tract infection; Sympt $=$ symptomatic urinary tract infection; Asympt $=$ asymptomatic urinary tract infection; Org $=$ organisms.

Organisms: $0=$ none found, $1=P s$. aeruginosa, $2=E$. coli, $3=K$. pneumoniae, $4=S$. aureus, $5=\beta$ hemolytic streptococci, $6=$ Gram positive cocci.

Treatment: $\mathrm{A}=$ co-trimoxazole $(160 \mathrm{mg}$ trimethoprim, $800 \mathrm{mg}$ sulfamethoxnzole) double strength $\mathrm{BID} \times 2$ days; $\mathrm{B}=$ Ampicillin $250 \mathrm{BID} \times 10$ days; $\mathrm{C}=$ Nalidixic acid $1 \mathrm{~g} \mathrm{QID} \times 10$ days; $\mathrm{D}=$ Norfloxacin $400 \mathrm{mg}$ BID $\times 7$ days; $\mathrm{E}=$ Gentamycin $\mathrm{QID} 8 \mathrm{H} \times 8$ days; $\mathrm{F}=$ Nitrofurantoin $50 \mathrm{mg}$ QID 1 month; $\mathrm{G}=$ Keflex $250 \mathrm{mg}$ QID $\times 7$ days. 
organisms per ml urine, no counts less than this were found) (8 patients) and bacterial adhesion to bladder cells. ${ }^{2}$ Antimicrobial therapy was administered for a total of 20 patient weeks, during which time 9 infections occurred for patients on co-trimoxazole (6), nitrofurantoin (2) and Keflex (1). This therapy was given only when signs $\left(>10^{5}\right.$ per ml urine counts) and symptoms were present (fever, malaise, spasticity and/ or fatigue), or the physician was concerned that kidney infection might be a risk. Of all the specimens taken, only the following were at a time when the patient was receiving antibiotics: patient no 1 , week 8 , $50 \mathrm{mg}$ TID nitrofurantoin; patient no 5, week 2, $50 \mathrm{mg}$ TID nitrofurantoin; patient no 8 , week $2,500 \mathrm{mg}$ every 6 hours ampicillin and week $4500 \mathrm{mg}$ every 8 hours Keflex; patient no 9 , week 1 , double strength co- trimoxazole; patient no 11, week 2, BID cotrimoxazole. Reference to Table III will show that 3 of these 6 specimens grew uropathogenic organisms, again emphasizing the lack of effectiveness of the treatment.

Table II Organisms recovered from the urine of 10 patients when UTI were detected as $>100,000$ bacteria per $\mathrm{ml}$ urine

\begin{tabular}{lc} 
Organisms & $\begin{array}{c}\text { Number of times } \\
\text { isolated }\end{array}$ \\
\hline Escherichia coli & 9 \\
Klebsiella pneumoniae & 8 \\
Pseudomonas aeruginosa & 3 \\
Staphylococcus epidermidis & 3 \\
$\beta$ hemolytic streptococci & 3 \\
Enterococcus faecalis & 1 \\
Enterobacter cloacae & 2 \\
\hline
\end{tabular}

Table III Presence of bacteriuria and bladder biofilms in 10 spinal cord injured patients over 4 to 8 week period

\begin{tabular}{|c|c|c|c|c|c|c|c|c|}
\hline \multirow[t]{4}{*}{ Patient } & \multicolumn{8}{|c|}{ Week of study } \\
\hline & \multirow{3}{*}{\multicolumn{8}{|c|}{$\begin{array}{l}\text { Urine culture positive/negative } \\
\text { Adherent bacteria found on bladder cells }\end{array}$}} \\
\hline & & & & & & & & \\
\hline & & & & & & & & \\
\hline \multirow[t]{2}{*}{1} & - & NT & NT & - & NT & NT & - & + \\
\hline & $\mathrm{AB}$ & NT & NT & NAO & NT & NT & NAO & NAO \\
\hline \multirow[t]{2}{*}{2} & - & - & - & NT & D & & & \\
\hline & NAO & NAO & $\mathrm{AB}$ & NT & $\mathrm{D}$ & & & \\
\hline \multirow[t]{2}{*}{3} & + & + & NT & $\mathrm{D}$ & & & & \\
\hline & $\mathrm{AB}$ & $\mathrm{AB}$ & NT & $\mathrm{D}$ & & & & \\
\hline \multirow[t]{2}{*}{5} & + & + & + & NT & NT & NT & + & $\mathrm{D}$ \\
\hline & $\mathrm{AB}$ & $\mathrm{AB}$ & $\mathrm{AB}$ & NT & NT & NT & $\mathrm{AB}$ & $\mathrm{D}$ \\
\hline \multirow[t]{2}{*}{6} & + & + & + & + & $\mathrm{D}$ & & & \\
\hline & $\mathrm{AB}$ & $\mathrm{AB}$ & $\mathrm{AB}$ & $\mathrm{AB}$ & $\mathrm{D}$ & & & \\
\hline \multirow[t]{2}{*}{7} & - & - & - & - & NT & - & + & + \\
\hline & $\mathrm{AB}$ & $\mathrm{AB}$ & $\mathrm{AB}$ & $A B$ & NT & $A B$ & $\mathrm{AB}$ & $A B$ \\
\hline \multirow[t]{2}{*}{8} & + & - & + & + & - & + & + & $\mathrm{D}$ \\
\hline & NAO & NAO & $\mathrm{AB}$ & $\mathrm{AB}$ & NAO & $\mathrm{AB}$ & $\mathrm{AB}$ & $\mathrm{D}$ \\
\hline \multirow[t]{2}{*}{9} & - & + & NT & + & NT & + & + & + \\
\hline & $\mathrm{AB}$ & $\mathrm{AB}$ & NT & $A B$ & NT & $A B$ & $A B$ & $A B$ \\
\hline \multirow[t]{2}{*}{10} & - & + & + & + & DS & & & \\
\hline & NAO & $\mathrm{AB}$ & $\mathrm{AB}$ & $\mathrm{AB}$ & DS & & & \\
\hline \multirow[t]{2}{*}{11} & & - & - & + & - & - & + & - \\
\hline & $\mathrm{AB}$ & NAO & NAO & $\mathrm{AB}$ & NAO & NAO & $\mathrm{AB}$ & NAO \\
\hline
\end{tabular}

$\mathrm{NT}=$ not tested, $\mathrm{D}=$ discharged, $\mathrm{DS}=$ discontinued study

+ positive urine culture

- negative urine culture

$\mathrm{AB}=$ bacterial biofilms present

$\mathrm{NAO}=$ no adherent organisms found 
The organisms isolated from urinary cultures taken during the study period are shown in Table II and represent $76 \%$ Gram negative rods and $24 \%$ Gram positive cocci. Patient no 6 had asymptomatic K. pneumoniae UTI for 4 weeks and was discharged untreated. Patient no 10 had untreated asymptomatic Ps. aeruginosa UTI for 3 weeks and was discontinued from the study for personal reasons.

Adherent bacterial biofilms were present on 8 of $49(16 \%)$ samples when the urine culture was negative, while cultures that were positive with no adherent organisms were seen in only 2 cases (4\%). The adhesion counts are presented in Table III along with the urine culture findings. The range of adherence counts was 3 to 75 bacteria per cell, with an average of $29 \pm 21$ for the Gram negative bacteria, and $29 \pm 10$ for the Gram positive cocci. While a count of 3 per cell was not regarded as a biofilm (which refers to a clump of adherent bacteria) it does indicate the deposition of organisms and the first stage of biofilm formation. We use the term 'colonized' to represent the presence of adherent bacteria. We are not comfortable referring to these as 'infected', as that implies signs, symptoms and other clinical criteria. This does not mean that the colonized cells nor the patient from whom they came were not infected.

Interestingly, the bladder cells examined appeared to be colonized by one dominant type of organism and not to be well covered with both Gram negative and Gram positive bacteria. The mean counts for 12 samples from patients on antimicrobial therapy were: $0,0,8,12,13,19,21,26,38,40,65$ and 75 bacteria per cell, giving an overall average of $32 \pm 22$.

The organisms found in the urine corresponded with those found on bladder cells on all occasions except patient no 5, weeks 2 and 3. Note also that patient no 7 was colonized on the bladder by Gram negative bacteria for weeks 1 to 4 , then with Gram positive cocci from weeks 6 to 8 , even although he was asymptomatic and not given antibiotics.

Scanning electron microscopy illustrated the extent of dense biofilm formation adherent to the bladder cells of one patient with
K. pneumoniae asymptomatic infection (Fig 1). The Klebsiella produced strand-like glycocalyx material that linked the organisms together even while in planktonic form suspended in the urine (Fig 2). Interestingly, coccal organisms (found by culture to be coagulase-negative staphylococci) were found coaggregating with the Klebsiella within the adherent biofilms, yet they were low in number in the urine (Fig 1).

\section{Discussion and conclusions}

This study demonstrated several particularly interesting findings. Firstly, adherent bacterial biofilms were found to occur on the bladder epithelium of $10 \mathrm{SCI}$ patients at some point during a one to two month period. The range of adhesion counts and standard deviations from the mean are typical of results found previously. ${ }^{11,12}$ However, the adhesion counts were higher than those previously regarded for uropathogens on cells of patients who are asymptomatic. ${ }^{8}$ This would suggest that (a) more receptor cells might exist on the bladder cells of spinal cord injured patients; (b) more receptors might exist on the surfaces of cells from adult males (as 7 of the 10 patients were, compared to Svanborg's premenopausal female sampling); or (c) previous in vitro adhesion data does not correlate with in vivo findings where high levels of bacterial adhesion can be found in asymptomatic patients. Our proposition is that at least the third of the three hypotheses is correct, based upon the latest findings and a previous study of adult females which showed that $E$. coli adhesion counts in vivo could range from 5 to 82 bacteria per cell, even when the patients were symptomatic. ${ }^{13}$ The fact that the urine culture did not detect bladder colonization in several instances supports the concept that planktonic organisms are not always detached from biofilms in sufficient numbers to be detected. It also supports the role that adherent biofilms play in the infectious process, especially in recurrences. ${ }^{9,14}$ The photomicrograph was particularly effective in demonstrating a dense uropathogenic biofilm on the cells of an asymptomatic patient (Fig 1) and within the patient's urine (Fig 2). 


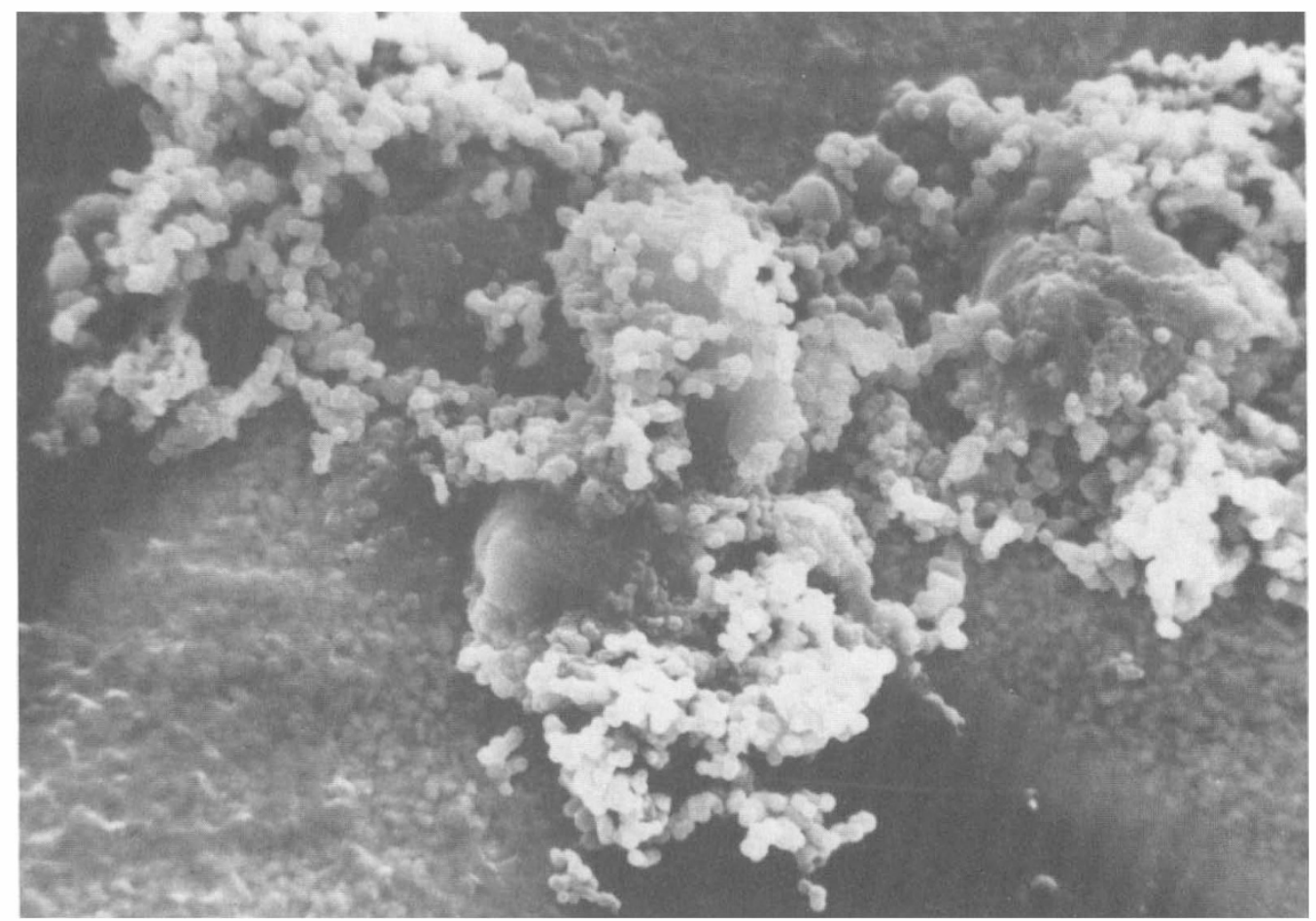

Figure 1 Scanning electron micrograph of bladder epithelial cells surrounded by dense adherent biofilms of $K$. pneumoniae coaggregating with coagulase-negative staphylococci. The uropathogenic bacteria are also seen in microcolonies that are not adherent to cells. The preparation came from a spinal cord injured patient with asymptomatic urinary tract infection caused by $K$. pneumoniae.

The biofilms appeared to have been resistant, to some extent, to the action of antimicrobial agents, including co-trimoxazole and nitrofurantoin which are commonly used to treat UTI. ${ }^{5}$ This is deduced from the finding of viable biofilms during therapy and the well documented knowledge that adherent biofilms can resist high levels of antimicrobial activity. ${ }^{9}$ It should be noted that the susceptibility tests performed by the microbiology laboratory on planktonic urinary isolates indicated that the pathogens were sensitive to the antimicrobial agents prescribed. However, when these same organisms existed in biofilms, they were able to resist the action of the prescribed drugs. This further emphasizes a need to improve our diagnostic techniques to enable the physician to better treat the patient.

Recent studies, however, have shown that 'young' biofilms (under 2 days old) may not have developed a dense glycocalyx matrix and a mechanism to resist antimicrobial action. ${ }^{15}$ Thus, the successful eradication of biofilms in $50 \%$ of the treated patients may have been due to the presence of these young biofilms.

The types of organisms isolated here were not different from those reported by Kuhn and associates ${ }^{14}$ who examined in great depth the effect of intermittent self catheterization on infection. The finding of $35 \% E$. coli is much lower than the $60-80 \%$ found in simple acute UTI in otherwise healthy adult females. Rather, it would appear to reflect a pattern found with complicated UTI, especially in hospital settings. ${ }^{16}$

Urinary tract infections still remain a problem in SCI patients and the policies for antibiotic therapy are a matter of discussion. ${ }^{4,17}$ The one scenario not addressed here but still a matter of controversy is what 


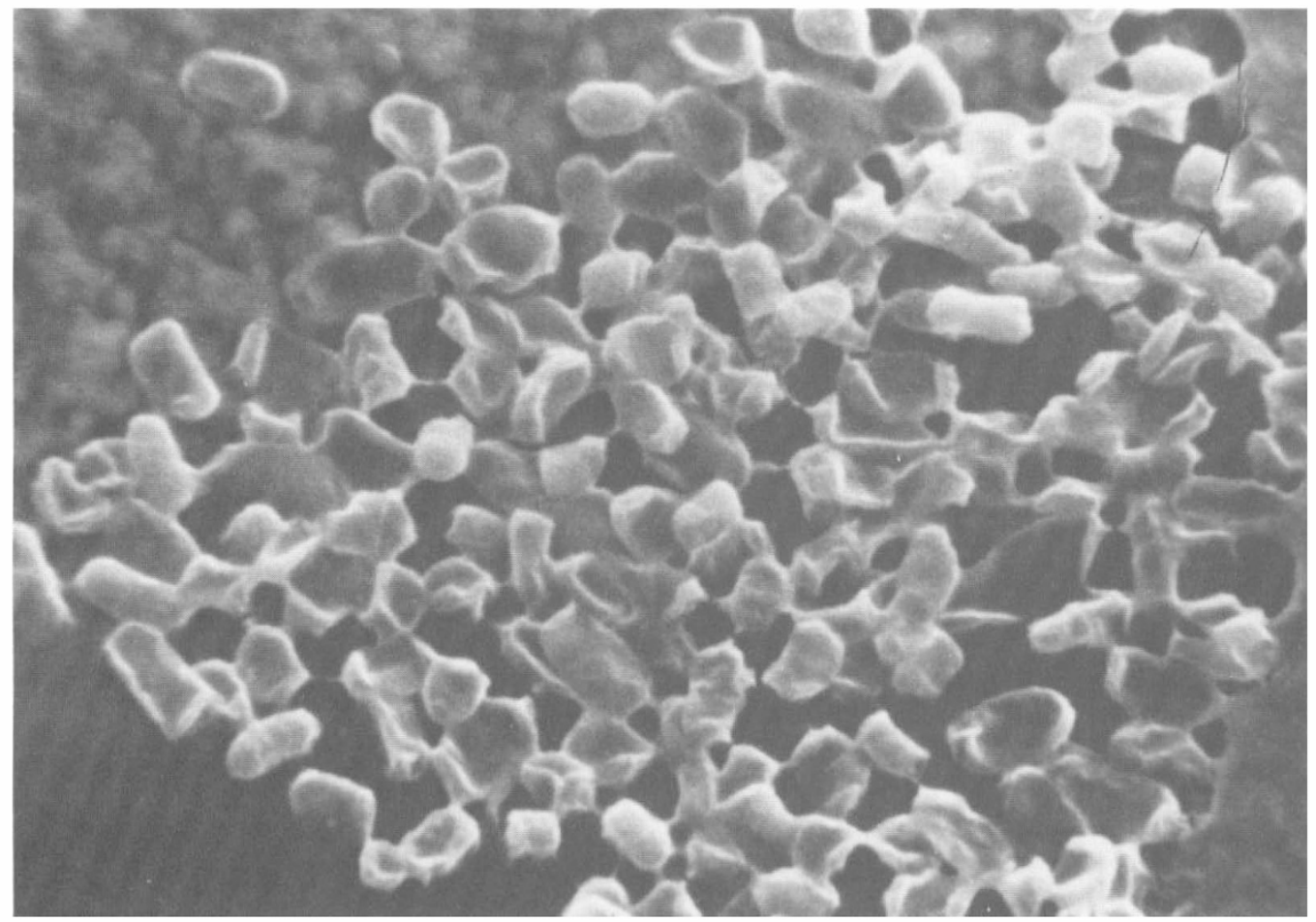

Figure 2 Scanning electron micrograph of urine sample from spinal cord injured patient with symptomatic urinary tract infection caused by $K$. pneumoniae. Although these organisms formed biofilms adherent to bladder cells, they also existed in non attached aggregated biofilms suspended in the patient's urine, as seen in this micrograph. The strand-like glycocalyx matrix is evident binding the cells together. A few coccal organisms (found on culture to be coagulase-negative staphylococci) can be seen on this micrograph and were also evident on adjacent fields of view.

bladder colonization and significant bacteriuria means when the patient is asymptomatic. For example, 2 patients were colonized by pathogenic $K$. pneumoniae and Ps. aeruginosa, yet did not then develop symptoms within the study period. The fact that the types of bacteria changed in patient no 7 between weeks 4 and 6 , and that the bladder of patient no 11 apparently cleared the adherent organisms between weeks 1 and 3 , then weeks 4 and 5 , suggests that the process is complex and must inevitably have something to do with host factors.

In conclusion, examination of bladder cells can be useful in detecting uropathogens especially when urine samples from SCI patients may be difficult to obtain or open to contamination. The finding of biofilms on the bladder of symptomatic patients, after therapy has been administered, should in- dicate that higher levels of antimicrobial agents are required, or drugs with better biofilm penetration ability such as ciprofloxacin (Preston, Khoury, Reid et al, manuscript submitted) should be given. However, the question of whether antibiotics should be used at all in asymptomatic bacteriuria remains another topic of discussion.

\section{Acknowledgements}

This work was funded by a grant from the Medical Research Council of Canada, with some technical support from funds supplied by Miles Pharmaceuticals and The University Research Incentive Fund of Ontario. We appreciate the cooperation of the patients of Parkwood Hospital, and the assistance of Ms Christina Tieszer and Mr Ross Davidson in helping with the electron microscopy. 


\section{References}

1 Warren JW, Damron D, Tenney JH, Hoopes JM, Deforge B, Muncie HL Jr (1987) Fever, bacteremia, and death as complications of bacteriuria in women with long-term urethral catheters. J Infect Dis 155: 1151-1158.

2 Warren JW, Tenney JH, Hoopes JM, Muncie HL, Anthony WC (1982) A prospective microbiological study of bacteriuria in patients with chronic indwelling urethral catheters. J Infect Dis 146: 719-723.

3 Johnson JR, Stamm WE (1989) Urinary tract infections in women: diagnosis and treatment. Ann Intern Med 111: 906-917.

4 Stickler DJ, Chawla JC (1988) An appraisal of antibiotic policies for urinary tract infections in patients with spinal cord injuries undergoing long-term intermittent catheterization. Paraplegia 26: 215-225.

5 Reid G, Lam D (1991) Diagnosis and therapy for urinary tract infections. Curr Opin Infect Dis 4: 42-46.

6 Bruce AW, Reid G. (1990) Investigation of infection of the lower urinary tract. In: O'Reilly PH, George NJR, Weiss RM, editors. Diagnostic Techniques in Urology. WB Saunders Co, Toronto: 483-489.

7 Reid G, Sobel JD (1987) Bacterial adherence in the pathogenesis of urinary tract infection: a review. Rev Infect Dis 9: 470-487.

8 Svanborg Eden C, Hanson LA, Jodal U, Lindberg U, Sohl Akerlund A (1976) Variable adherence to normal human urinary-tract epithelial cells of Escherichia coli strains associated with various forms of urinary-tract infection. Lancet 2: 490-492.

9 Costerton JW, Cheng K-J, Geesey GG, Ladd TI, Nickel JC, Dasgupta M et al (1987) Bacterial biofilms in nature and disease. Ann Rev Microbiol 41: 435-464.

10 Nickel JC, Gristina AG, Costerton JW (1985) Electron microscopic study of an infected Foley catheter. Can J Surg 28: 50-52.

11 Reid G, Brooks HJL (1984) In vitro attachment of Escherichia coli to human epithelial cells. $N Z$ Med J 97: 439-442.

12 Reid G, Brooks HJL, Bacon DF (1983) In vitro attachment of Escherichia coli to human uroepithelial cells. Variation in receptivity during the menstrual cycle and pregnancy. J Infect Dis 148: 412-421.

13 Reid G, Brooks HJL (1985) A fluorescent antibody staining technique to detect bacterial adherence to urinary tract epithelial cells. Stain Technol 60: 211-217.

14 Kuhn W, Rist M, Zaech GA (1991) Intermittent urethral self-catheterization: long term results (bacteriological evolution, continence, acceptance, complications). Paraplegia 29: 222-232.

15 Anwar H, Costerton JW (1990) Enhanced activity of combination of tobramycin and piperacillin for eradication of sessile biofilm cells of Pseudomonas aeruginosa. Antimicrob Agents Chemother 34: $1666-1671$.

16 Preston CAK, Bruce AW, Reid G (1992) Antibiotic resistance of urinary pathogens isolate from patients attending The Toronto Hospital between 1986 and 1990. J Hosp Infection 21.

17 Maynard F, Diokno A (1984) Urinary infection and complications during clean intermittent catheterization following spinal cord injury. J Urol 132: 943-946. 